\title{
Employees' Perception about Social Accounting Practice by Commercial Banks of Bangladesh
}

\author{
Mehdina Kabir Tamanna \\ Lecturer of Accounting, Department of Business Administration, Central Women's University, 6 Hatkhola Road, Dhaka-1203 BANGLADESH \\ *E-mail for correspondence: mehdina_tamanna@hotmail.com
}

https://doi.org/10.18034/abr.v8i2.154

\begin{abstract}
In banking industry social accounting has become an important phenomenon now a days. This practice by commercial banks creates a bridge between society/country and banks. The bank employees are highly motivated to do this for societal concern as well as corporate benefit. This study is conducted on 100 employees of some commercial banks of Dhaka, Bangladesh. Random sampling method was used to select the respondents. The study reveals bank employees' perception about social accounting which is carried out by their own banks. Banks' main focus is society/community while doing social accounting. Statistical tools like (mean, standard deviation, variance, frequency, correlation analysis) are used to find out the result by using SPSS software. The study reveals there is a positive relationship between social accounting with corporate competitiveness \& social interaction. The commercial banks have to come forward to involve in practicing social accounting for economic development of Bangladesh.
\end{abstract}

Key words: Social Accounting, Employees' perception, Commercial banks, Bangladesh

\section{INTRODUCTION}

Social Accounting has become an integral part of long term sustainable strategy \& growing practice in domain of today's banking industry. Social Accounting is the process of communicating the social and environmental effects of organizations' economic actions to particular interest groups within society and to society at large. It is known as Social Accounting \& Auditing, Social Accountability, Social \& Environmental Accounting, Corporate Social Responsibility Reporting etc. In 2008, Bangladesh Bank initiated the campaign of social responsibility campaign by organizations in financial sector of Bangladesh. This initiative encourages banks to apply social \& environmental accounting practices for greater context. In recent times, almost every bank is engaged in doing this social accounting practice. They do this for their corporate benefit as well as for societal concerns. The bank employees are directly related to this work. This paper focuses on the perception of employees towards social accounting practices by commercial banks of Dhaka city in Bangladesh.

\section{RATIONALE FOR THE STUDY}

Banks play a vital role in the economy of Bangladesh for commercial and industrial purpose. In recent time, social purpose has been added also in this segment. Banks are carrying out social responsibility through social accounting practice. The employees are engaged in doing this from their social concerns \& responsibility towards country. This study incorporates the social accounting practices performed by commercial banks and the perception of banks' employees in doing this.

\section{OBJectives OF THE STUdY}

The main objective of the study is to highlight bank employees' perception about social accounting practices carried out by commercial banks. Specific objectives are-

- To explore the impact of commercial bank's performance in terms of social interaction \& social welfare.

- To know how social accounting practice helps a bank to sustain in competitive market.

\section{Methodology OF THE STUdy}

The study has been conducted in Dhaka city of Bangladesh. The main purpose of the study is to know the perception of employees' about social accounting practices carried out by their banks. For this purpose a survey has been conducted which is based on questionnaire. 100 respondents 
participated in the survey who is involved in banks' social accounting practices. Although the study is mainly based on primary data but both primary and secondary data are used here. There were two sections on the questionnairegeneral section and analytic section. General section includes information about banks' involvement on social accounting works and their focus and target about this. Analytic section covers the questions related to banks' involvement in social accounting practices and the employees' own perceptions about this. This section also covers their opinion related to corporate competitiveness \& social interaction. For measuring employees' perception about this, a 5 point Likert scale has been used. The sample size was 100 employees of different commercial banks from Dhaka city. Random sampling method was used in selection of the respondents. Secondary data has been collected from different web portals, articles etc. For analyzing the data different statistical tools like Mean, Standard deviation, variance, frequency, correlation analysis by SPSS software have been used.

\section{LITERATURE REVIEW}

To counter the lack of attention to social benefits and the effect of business practices on the environment, by the 1960s a new concept called social responsibility accounting was proposed in the theoretical field of accounting. Anderson and et al. (1989) mentioned this in their writing. Social Accounting is an approach began developing in UK in early 1970s.

With the increase in the importance of environmental issues, social responsibilities, reporting and risk management, accounting needs have changed (Carnegie \& Napier, 2010). Social Accounting includes compiling, measuring \& reporting social commitments \& other transactions and the mutual effects of these transactions between corporations and their surroundings. The purpose of social accounting is to provide information to evaluate the effects of firms' activities on society.

The American Accounting Association's Committee on Accounting for Social Performance (1975), while attempting to explain social accounting stated that '.... not surprisingly for a developing area, there is little agreement as to the boundaries'. Gray and et al (1987) discussed the role of conventional accounting in result reports and asserted that instead of basing accountability on possession it is better to consider beneficiaries. The three steps of planning, accounting \& reporting and auditing called commonsense approach of social accounting has been developed in Australia (Cameron and et al, 2010). Bangladesh has recently enacted very important laws such as the Bangladesh Environment Conservation Act, 1995, the Environment Conservation Rules, 1997, the Environment Court Act, 2000. Moreover, the important environmental policy and Action plan were formulated in 1992 for the conservation and development of the environment in Bangladesh.
As social accounting in its various forms increases, so too do the frameworks and guidelines devised to assist firms in producing social and environmental information. It also has stakeholder engagement as a fundamental principle (Stanwick and Stanwick, 2006). Social Accounting enables employees to apply bank policies for meeting the needs and benefits of its stakeholders. Nowadays commercial banks are expected to be committed to the long term needs of society. So, the practice of social accounting is increasing in Bangladesh day by day.

Baron (2001) mentioned that using CSR in a firm can lead to attract customers and can provide a good business strategy. Social responsibility accounting must include revealing information to beneficiaries, providing feedback for management and improving environmental projects.

Islam et al, (2012) suggested in their study that social audit guideline should be developed to measure and verify the social responsibility. They also found that In Bangladesh social accounting may implement step by step in all aspects of an organizations.

The involvement of the profession of accounting is needed in adoption and promotion of corporate social \& environmental responsibility. Though there are few studies regarding social accounting practices in Bangladesh but a lot of scope is available for social accounting practices in banking sector of Bangladesh.

\section{Scope of Social Accounting Practice by COMMERCIAL BANKS}

Social information system, social reporting, social accounting, social disclosure, corporate social performance, etc are used interchangeably for one another. They underline that corporate enterprises have a responsibility to maintain and promote quality of life of the community. The main aim of banks' is not only doing successful business but also showing responsibility towards the society. For this reason, commercial banks are accountable to a broader group of stakeholders. Banks carries out social responsibility towards their clients, investors, community, competitors and the country as a whole. These banks adopt environmental care, tree plantation, health care, community involvement, educational support \& other peripheral development of the society. By doing these, banks promote their corporate image, get commercial advantage of new markets and make a healthy relationship with community.

\section{DATA ANALYSIS AND Discussion}

In this study data has been collected randomly from 100 employees of different commercial banks. The respondents express their thinking \& view about banks' social accounting practices. From their answers the following results have been found: 
Table 1: Main focus, adopted steps \& benefits of doing social accounting by banks

\begin{tabular}{|c|c|c|c|c|}
\hline \multicolumn{2}{|l|}{ Basic Information } & \multirow{2}{*}{$\begin{array}{c}\begin{array}{c}\text { No. of } \\
\text { respondents }\end{array} \\
31\end{array}$} & \multirow{2}{*}{$\begin{array}{c}\text { Percentage } \\
31\end{array}$} & \multirow{2}{*}{$\begin{array}{c}\begin{array}{c}\text { Cumulative } \\
\text { Percentage }\end{array} \\
31\end{array}$} \\
\hline Main focuses while doing social accounting & Customers/Clients & & & \\
\hline & Investors & 06 & 06 & 37 \\
\hline & Society/Community & 62 & 62 & 99 \\
\hline & Competitors & 01 & 01 & 100 \\
\hline \multicolumn{2}{|l|}{ Total } & 100 & 100 & \\
\hline \multirow[t]{5}{*}{ Steps adopted by banks } & $\begin{array}{l}\text { Environmental care \& tree } \\
\text { plantation }\end{array}$ & 13 & 13 & 13 \\
\hline & Health care & 09 & 09 & 22 \\
\hline & Community involvement & 27 & 27 & 49 \\
\hline & Education \& scholarships & 49 & 49 & 98 \\
\hline & Peripheral development & 02 & 02 & 100 \\
\hline \multicolumn{2}{|l|}{ Total } & 100 & 100 & \\
\hline \multirow[t]{5}{*}{ Benefits for doing this } & Promotion of corporate image & 21 & 21 & 21 \\
\hline & Greater employee satisfaction & 11 & 11 & 32 \\
\hline & $\begin{array}{l}\text { Commercial advantage of } \\
\text { new markets }\end{array}$ & 16 & 16 & 48 \\
\hline & Media coverage & 03 & 03 & 51 \\
\hline & $\begin{array}{l}\text { Good relation with } \\
\text { community }\end{array}$ & 49 & 49 & 100 \\
\hline Total & & 100 & 100 & \\
\hline
\end{tabular}

Source: Data collected from the respondents of survey

From the above table it is shown that the main focus of doing social accounting is based on customers, investors, society and competitors. Most of the bank employees have told society/community (62\%) is the main focus of their social accounting practice. Then they think about their customers/clients which is (31\%). they also show their social responsibilities towards the investors $(6 \%)$ \& competitors (Which is very low $1 \%$ ).

Commercial banks take various social accounting steps towards their targets. The major step is funding in education \& scholarships, which is $49 \%$. They also show their corporate responsibilities towards community involvement $(27 \%)$, environmental care \& tee plantation $(13 \%) \& 9 \%$ on health care. They contribute very little in peripheral development also which is only $2 \%$ according to the survey.
By engaging in this type of social activities the banks get a lot of benefits. They enlarges their corporate image, get proper employee satisfaction, build up a good relation with community etc. From this survey it is shown that most of the banks are practicing social accounting with an aim to build up strong relation with community (49\%). Another benefits are promotion of corporate image that is $21 \%$, commercial advantage of new markets (16\%), to ensure greater employee satisfaction $(11 \%)$ and only $3 \%$ for media coverage.

\section{Area of responsibility \& concrete action of banks:}

The following table shows commercial banks area of responsibility while practicing social accounting and also the action which is taken by banks. The information is given below-

Table 2: Area of responsibility \& concrete action taken by banks

\begin{tabular}{|l|l|c|c|c|}
\hline \multicolumn{2}{|c|}{ Basic Information } & $\begin{array}{c}\text { No. of } \\
\text { respondents }\end{array}$ & Percentage & $\begin{array}{c}\text { Cumulative } \\
\text { Percentage }\end{array}$ \\
\hline Area of responsibility & Responsibility towards clients & 26 & 26 & 26 \\
\hline & Responsibility towards community & 27 & 27 & 53 \\
\hline & Responsibility towards country & 47 & 47 & $\mathbf{1 0 0}$ \\
\hline & Total & $\mathbf{1 0 0}$ & $\mathbf{1 0 0}$ & \\
\hline Concrete action of banks & Cause related marketing campaign & 12 & 12 & 12 \\
\hline & Donations for social \& environmental utility & 41 & 41 & 53 \\
\hline & Sponsorship of sports \& cultural events & 10 & 10 & 63 \\
\hline & Educational help & 19 & 19 & 82 \\
\hline & Health care & 18 & 18 & $\mathbf{1 0 0}$ \\
\hline & Total & $\mathbf{1 0 0}$ & $\mathbf{1 0 0}$ & \\
\hline
\end{tabular}

Source: Data collected from the respondents of survey 
Here shows commercial banks show their responsibilities towards country, community \& clients. Banks' employees are involved in social accounting works and their major responsibility is to serve the country. $47 \%$ of employees agree with that, while there is a close competition between responsibility towards community $(27 \%)$ \& responsibility towards clients $(26 \%)$. For doing these, employees of banks are involved in various social works. Majority of the employees have told that their banks donate for social \& environmental utility $(41 \%)$, help in educational sector $(19 \%)$, contribute in health care $(18 \%)$ \& cause related marketing campaign (12\%). The employees say banks also sponsor for sports \& cultural events $(10 \%)$.

\section{Frequency Table}

100 respondents were asked about banks' involvement in social accounting practice, corporate competitiveness and social interaction with banks and society. 5 point Likert scale ( $1=$ Strongly agree, $2=$ Agree, $3=$ Neither agree nor disagree, $4=$ Disagree \& $5=$ strongly disagree) was used to get the answer. It is shown in the following frequency tables.

Table 3: Banks' involvement in social accounting practice

\begin{tabular}{|c|c|c|c|c|c|}
\hline \multicolumn{2}{|c|}{} & Frequency & Percent & $\begin{array}{c}\text { Valid } \\
\text { Percent }\end{array}$ & $\begin{array}{c}\text { Cumulative } \\
\text { Percent }\end{array}$ \\
\hline Valid & Strongly Agree & 85 & 85.0 & 85.0 & 85.0 \\
\cline { 2 - 6 } & Agree & 12 & 12.0 & 12.0 & 97.0 \\
\cline { 2 - 6 } & $\begin{array}{c}\text { Neither agree } \\
\text { nor disagree }\end{array}$ & 3 & 3.0 & 3.0 & 100.0 \\
\cline { 2 - 6 } & Total & 100 & 100.0 & 100.0 & \\
\hline
\end{tabular}

Among 100 respondents the frequency and valid percentages along with cumulative percentage are shown in the above table. Most of the respondents strongly agree with the statement that their banks are involved in social accounting practice. Few number of respondents agree with the statement and only $3 \%$ of respondents have given their neutral opinion about social accounting practice by their banks. No respondents disagree or strongly disagree with the statements. That means almost every banks are engaged in doing social accounting \& the bank employees are well aware about this.

Table 4: Social Accounting promotes corporate competitiveness

\begin{tabular}{|c|c|c|c|c|}
\hline & Frequency & Percent & \begin{tabular}{|c|} 
Valid \\
Percent
\end{tabular} & $\begin{array}{c}\text { Cumulative } \\
\text { Percent }\end{array}$ \\
\hline Valid Strongly Agree & 42 & 42.0 & 42.0 & 42.0 \\
\hline Agree & 54 & 54.0 & 54.0 & 96.0 \\
\hline $\begin{array}{l}\text { Neither agree } \\
\text { nor disagree }\end{array}$ & 4 & 4.0 & 4.0 & 100.0 \\
\hline Total & 100 & 100.0 & 100.0 & \\
\hline
\end{tabular}

The bank employees think that practicing social accounting promotes corporate competitiveness among the commercial banks. The table shows 42 respondents strongly agree \& 54 respondents agree with this statement, while 4 respondents are neither agree nor disagree with this. No respondents disagree or strongly disagree with the statement. The frequency of respondents is shown in the table.

Table 5: Social accounting has an interaction between society \& banks

\begin{tabular}{|c|c|c|c|c|}
\hline & Frequency & Percent & \begin{tabular}{|c|} 
Valid \\
Percent
\end{tabular} & $\begin{array}{c}\text { Cumulative } \\
\text { Percent }\end{array}$ \\
\hline \begin{tabular}{|l|l} 
Valid Strongly Agree \\
\end{tabular} & 47 & 47.0 & 47.0 & 47.0 \\
\hline Agree & 48 & 48.0 & 48.0 & 95.0 \\
\hline $\begin{array}{c}\text { Neither agree } \\
\text { nor disagree }\end{array}$ & 5 & 5.0 & 5.0 & 100.0 \\
\hline Total & 100 & 100.0 & 100.0 & \\
\hline
\end{tabular}

Another statement is social accounting has an interaction between society \& banks. From the frequency table it is shown that most of the respondents strongly agree \& agree with the statement. But $5 \%$ of the respondents have given their neutral opinion here. No respondents disagree or strongly disagree with the statement.

Table 6: Statistics

\begin{tabular}{|c|c|c|c|c|}
\hline \multicolumn{2}{|c|}{} & $\begin{array}{c}\text { Banks' } \\
\text { involvement } \\
\text { in social } \\
\text { accounting } \\
\text { practice }\end{array}$ & $\begin{array}{c}\text { Social } \\
\text { Accounting } \\
\text { promotes } \\
\text { corporate } \\
\text { competitiveness }\end{array}$ & $\begin{array}{c}\text { Social } \\
\text { accounting has } \\
\text { an interaction } \\
\text { between society } \\
\& \text { banks }\end{array}$ \\
\hline \multirow{2}{*}{$\mathrm{N}$} & Valid & 100 & 100 & 100 \\
\cline { 2 - 5 } & Missing & 0 & 0 & 0 \\
\hline Mean & 1.1800 & 1.6200 & 1.5800 \\
\hline Std. Deviation & .45793 & .56461 & .58913 \\
\hline Variance & .210 & .319 & .347 \\
\hline
\end{tabular}

Table 6 shows 100 bank employees' response about the social accounting practice, corporate competitiveness \& social interaction. Mean, standard deviation and variance are calculated here. For 'Banks' involvement in social accounting practice 'the mean value is 1.18, Std. Deviation is .46 and Variance is .21. For 'Social Accounting promotes corporate competitiveness' statement the mean value is 1.62 , Std. Deviation is .56 and Variance is .32.Again the mean value for 'Social accounting has an interaction between society \& banks' is 1.58 ,Std. Deviation is .59 and the variance is .35 . These represent almost every bank is involved in social accounting practice, it promotes competitiveness among banks and creates an interaction between society \& banks.

\section{Hypotheses Testing}

The employees of commercial banks showed their view and opinion that the more banks do social accounting the more corporate competitiveness increase among banks and thus a social interaction is built up between society \& banks. Their opinions are analyzed by testing the following hypothesis.

\section{Hypothesis \#01}

$\mathrm{H}_{0}$ : There is no positive relationship between banks' social accounting practice with corporate competitiveness \& social interaction. 
$\mathrm{H}_{1}$ : There is positive relationship between banks' social accounting practice with corporate competitiveness \& social interaction.

\section{Hypothesis \#02}

$\mathrm{H}_{0}$ : There is no significant relationship between banks' corporate competitiveness by doing social accounting \& social interaction of banks.

$\mathrm{H}_{1}$ : There is significant relationship between banks' corporate competitiveness by doing social accounting \& social interaction of banks.

\section{Results}

The following co-relation analysis was conducted by considering the following variables:

Table 7: Correlations

\begin{tabular}{|c|c|c|c|c|}
\hline & & $\begin{array}{c}\text { Banks' } \\
\text { involvem } \\
\text { ent in } \\
\text { social } \\
\text { accounti } \\
\text { ng } \\
\text { practice }\end{array}$ & $\begin{array}{c}\text { Social } \\
\text { Accounti } \\
\text { ng } \\
\text { promotes } \\
\text { corporate } \\
\text { competiti } \\
\text { veness } \\
\end{array}$ & $\begin{array}{c}\text { Social } \\
\text { accountin } \\
\text { g has an } \\
\text { interaction } \\
\text { between } \\
\text { society \& } \\
\text { banks }\end{array}$ \\
\hline \multirow{3}{*}{$\begin{array}{c}\text { Banks' } \\
\text { involvement in } \\
\text { social } \\
\text { accounting } \\
\text { practice }\end{array}$} & $\begin{array}{c}\text { Pearson } \\
\text { Correlation }\end{array}$ & 1 & $.384^{* *}$ & .133 \\
\hline & $\begin{array}{l}\text { Sig. (2- } \\
\text { tailed) }\end{array}$ & & .000 & .186 \\
\hline & $\mathrm{N}$ & 100 & 100 & 100 \\
\hline \multirow{3}{*}{$\begin{array}{c}\text { Social } \\
\text { Accounting } \\
\text { promotes } \\
\text { corporate } \\
\text { competitiveness }\end{array}$} & $\begin{array}{c}\text { Pearson } \\
\text { Correlation }\end{array}$ & $.384^{* *}$ & 1 & $.214^{*}$ \\
\hline & $\begin{array}{l}\text { Sig. (2- } \\
\text { tailed) }\end{array}$ & .000 & & .033 \\
\hline & $\mathrm{N}$ & 100 & 100 & 100 \\
\hline \multirow{3}{*}{$\begin{array}{c}\text { Social } \\
\text { accounting has } \\
\text { an interaction } \\
\text { between society } \\
\text { \& banks }\end{array}$} & $\begin{array}{c}\text { Pearson } \\
\text { Correlation }\end{array}$ & .133 & $.214^{*}$ & 1 \\
\hline & $\begin{array}{l}\text { Sig. (2- } \\
\text { tailed) }\end{array}$ & .186 & .033 & \\
\hline & $\mathrm{N}$ & 100 & 100 & 100 \\
\hline \multicolumn{5}{|c|}{ **. Correlation is significant at the 0.01 level (2-tailed). } \\
\hline & & & & ailed). \\
\hline
\end{tabular}

Testing Hypothesis 01:

The result from correlation table shows a moderate, significant positive relationship between "Banks' involvement in social accounting practice \& Social accounting promotes corporate competitiveness" $(r=0.384, p<0.01)$. It suggests the commercial banks increase fair competition among them by doing more and more social accounting.

Again the result shows there is a positive relationship between "Banks' involvement in social accounting practice \& Interaction between society \& banks" ( $r=0.133$, $p>0.05)$.Here the significance level is 0.186 which is statistically not significant. But it is clearly shown in the table that when banks' social accounting increased, the interaction between society \& banks also increased.
As banks involvement in social accounting practices increased, corporate competitiveness among banks and interaction between society \& banks also increased, meaning data provide evidence to reject the null hypothesis. The alternative hypothesis is accepted that there is positive relationship between banks' social accounting practice with corporate competitiveness \& social interaction.

\section{Testing Hypothesis 02:}

The result from correlation table shows a moderate, significant positive relationship between "Social accounting promotes corporate competitiveness \& Banks' involvement in social accounting practice" $(r=0.384$, $p<0.01)$. When corporate competitiveness increased, social accounting practices also increased.

Again the result shows there is almost a moderate, significant positive relationship between "Social accounting promotes corporate competitiveness \& interaction between society \& banks" $(r=0.214$, $p<0.05)$.When corporate competitiveness increased, the interaction between society \& banks also increased.

As when banks' corporate competitiveness increased, social accounting practices \& social interaction of banks also increased, meaning data provide evidence to reject the null hypothesis. The alternative hypothesis is accepted that there is significant relationship between banks' corporate competitiveness by doing social accounting \& social interaction of banks.

\section{CONCLUSION}

The concept of social accounting generally encompasses the development of society at a large with getting corporate benefit. Almost every commercial banks of Bangladesh is involved in doing social accounting. Banks main focus is to serve the society by doing various social welfare activities and promote their corporate image. They show their responsibility towards country as a whole. The commercial banks play a fair competition with their competitors in market by practicing social accounting. This practice creates a positive relationship between banks \& society. From societal aspect banks contribute voluntarily in social accounting activities for social welfare. Every commercial banks of Bangladesh should implement policy regarding this issue. The research findings may applicable in this regard. As Bangladesh is a developing country the commercial banks should come forward to take necessary steps to reduce the poverty \& develop the country from their concern. As long as they are engaged in doing social accounting the country as a whole will be benefited for it. The more banks do social accounting the more social interaction between banks \& community will be increased. In this regard the researcher's suggestion is there should be social audit system to monitor bank's social accounting practices. Social accounting can play a vital role to represent 
Bangladesh in a very strong position in the world. As Bangladesh is an Asian country this research paper is very much germane to wider Asian context. For several decades the Asian region has shown fast economic growth and it is expected to grow. Asia plays a vital role in the global economy. Banks \& other Companies in the Asian region are involved in environmental issues for corporate \& societal concerns. They document their social contribution and contribute to sustainable development. The involvement of Asian commercial banks in social accounting can increase banks' sustainability \& corporate benefits. This research paper not only helps the banking sector of Bangladesh but also the wider Asian region will be benefited from this.

\section{REFERENCES}

American Accounting Association (1975), "Report of the Committee on Accounting for Social Performance." The Accounting Review, Vol.51, pp. 38-39+41-69.

Anderson, J.W., Jr. (1989). “Corporate Social Responsibility: Guidelines for top management", New York, NY: Quorum Books.

Azim, et. al. (2009). "Corporate Social Reporting Practice: Evidence from Listed Companies in Bangladesh", Journal of Asia-Pacific Business, Vol.10 No.2, pp. 130-145.

Baron, D. (2001). "Private politics, Corporate Social Responsibility and integrated Strategy", Journal of Economics $\mathcal{E}$ Management Strategy, Vol.10, pp.7-45.

Cameron, et. al. (2010). "Social Accounting: A Practical Guide for Small Community Organizations and Enterprises." Centre for Urban and Regional Studies, The University of Newcastle, Australia.

Carnegie, G.D., \& Napier, C.J. (2010). “Traditional accountants and business professionals: Portraying the accounting profession after Enron", Accounting, Organizations \& Society, Vol. 35 No.3, pp. 360-376.

Chowdhury, A.I \& Chowdhury, A.K. (1996). “Corporate social accounting: do we really need it?", The Bangladesh Accountant, Vol. April-June, pp.90-100.

Ferdous, M., \& Moniruzzaman, M. (2015). “An Empirical Evidence of corporate Social Responsibility by Banking Sector based on Bangladesh", Asian Business Review, Vol.3 No.4, pp.82-87.

Gray, et. al. (1987). "Corporate Social Reporting: Accounting \& Accountability." London: Prentice-Hall.

Gray, R. (2002). “The social accounting project \& accounting organizations \& society: Accounting is applied in the financial statements of companies in Gaza strip", Journal of Islamic University, Human Studies Series, Vol.15 No.1, pp.239-281.

Homayoun, S. et. al. (2015). “Corporate Social Responsibility and Its Relevance to Accounting", Journal of Sustainable Development, Vol.8 No.9, pp.178-187.
Islam, D.M.N. et. al. (2012). “Social Accounting Reporting Practices in Bangladesh-A Voluntary Approach", Indian Journal of commerce \& Management Studies, Vol.3 No.1, pp.1-8.

Islam, M., \& Hasan, M. (2016). “Corporate Social Responsibility of Commercial Bank in Bangladesh: A Comparative Study on Nationalized and Private Banks", Asian Business Review, Vol.6 No.1, pp.25-34.

Islam, M.N., Ahmed, T. \& Chowdhury, M.A.F. (2012). "Social Accounting Reporting Practices in Bangladesh", Indian Journal of Commerce \& Management Studies, Vol. 3, No. 1, pp.1-8

Khan, H.Z., et. al. (2009). "Corporate social responsibility (CSR) reporting: a study of selected banking companies in Bangladesh", Social Responsibility Journal, Vol.5 No.3, pp. 344-357.

Masud, M.A.K., \& Hossain, M.S. (2012). “Corporate Social Responsibility Practices in Bangladesh: A study of Selected Private Commercial Banks", IOSR Journal of Business $\mathcal{E}$ Management, Vol.6 No. 2, pp.42-47.

Masud, M.A.K., \& Kabir, M.H. (2016). "Corporate social responsibility evaluation by different levels of management of Islamic banks and traditional banks: evidence from banking sector of Bangladesh", Problems \& Perspective in Management, Vol.14 No.3, pp.194-202.

Mohammad, D.N. et. al. (2013). "Overview of the Bangladesh Environment Conservation Act 1995", Australian Journal of Basic and Applied Sciences, Vol. 7 No.2, pp. 156-174.

Stanwick, P.A., \& Stanwick, S.D. (2006), “Environment and Sustainability Disclosures: A Global Perspective on Financial Performance", In Allouche, J. (Ed.), Corporate Social Responsibility Volume 2: Performances and Stakeholders, Palgrave Macmillan, New York.

Yunus, M. et. al. (2015). "Corporate Social Responsibilities and Related Disclosures: A Study on the Listed Banks in Bangladesh", World Journal of Social Sciences, Vol. 5 No.1, pp.1-21.

$$
--0--
$$

\section{ACKNOWLEDGEMENT}

At first I want to thank Almighty Allah for giving me this opportunity to prepare the report. During the survey I got tremendous support from some persons and banks. It was unable to conduct the research without their assistance. The bank employees helped me a lot to get information about the survey. Though they had busy schedule of work but they gave me positive response when the questionnaires were placed to them. My research became convenient when they gave me the internal information of their banks. Finally I want to give thanks to Asian Business Review (ABR) for creating space for me where I can publish my paper. 